\title{
The Potentiality of Principal Leadership Implementation In North Sumatera
}

\author{
Wildansyah Lubis \\ Faculty of Educational Science, Universitas Negeri Medan \\ Medan, Indonesia
}

Syaiful Sagala

Faculty of Economics, Universitas Negeri Medan

Medan, Indonesia

\author{
Abdul Hasan Saragih \\ Faculty of Engineering, Universitas Negeri Medan \\ Medan, Indonesia \\ Gaffar Hafiz Sagala \\ Faculty of Economics, Universitas Negeri Medan \\ Medan, Indonesia
}

\begin{abstract}
Previous researchers have had a long debate about the urgency of the application of transformational and instructional leadership models for educational organizations. Nevertheless, there is a stream of research that seeks to bridge the conflict by recommending the adoption of principal leadership in educational organizations. Principal leadership combines the advantages of transformational and instructional leadership applications in a leadership model. While it still has many contradictions in its form, the potential use of this leadership model needs to be explored further to get a useful leadership model in schools. This study aims to investigate how teachers respond to principal leadership practices. The response is assessed by principal leadership indicators that may be practiced naturally. This study using survey method to collecting the data with the help of questionnaires to high school teachers in North Sumatra, Indonesia. With purposive sampling and snowball techniques, this study received 352 responses. The responses are then tabulated and analyzed using factor analysis. The results of this study indicate the potential application of principal leadership in North Sumatra. The application of leadership principals systematically can increase the effectiveness of schools that will have implications for improving teacher performance and student achievement.
\end{abstract}

Keywords- Principal Leadership, Potentiality Implementation, School Effectiveness, North Sumatera

\section{INTRODUCTION}

Various researchers consistently have found the school leader's leadership has a positive impact towards student's academic performance, even more than the impact which given by the school itself [1]. Those impacts gained by maximizing organization role, while school leader's leadership is a crucial instrument to optimizing those organization function [2,3]. Therefore, the problem arises between weak leadership relationships with organizational capacity, making school effectiveness low, which in turn to reduce the positive impact of school leader's leadership towards student achievement [1].

Previous studies have revealed that school leaders and school supervisors can use their power directly to control the teacher's teaching quality and ensure the delivery of materials according to school academic goals $[4,5,6]$. Moreover, the school leader also has the power to control various services at school to ensure the quality of academic services.

Experienced by students [6]. At higher levels, such as districts/municipalities and provinces, leadership in professional education organizations can improve the effectiveness and efficiency of the organization in controlling the performance of school leaders, school supervisors and education boards in education provision innovation $[7,8,9]$. Therefore, leadership style and organizational design in the province, district/municipality, and school level are integral parts that cannot stand by itself. The synergic of various levels of leadership and educational organizations will be able to provide a conducive learning atmosphere which will reduce the level of stress in learning, maintain the growth of reasoning and students creativity. In various leadership studies, the instructional and transformational leadership models have dominated the empirical and normative studies about school leader's leadership triumph [10,11].

However, Leithwood [1] views both models of leadership not adequately shaping school effectiveness and revealing the need for research on alternative patterns about leadership distribution that possibly done between school leaders, department heads and the relative contribution toward school improvement with any offered alternative. Several other studies $[2,4,10]$ offer a model of principal leadership that becomes an alternative between the conflict of instructional and transformational leadership models. Principal leadership model offers a leadership model adapted from the needs of the organization that in practice will be valuable in the various organizational contexts [2]. This view certainly in line with Hofstede's [12] view which indicates that each region has different management culture, so the success of organizational management in developed countries is not necessarily appropriate in other regions. Therefore, to get an appropriate leadership model, it depends on the organization on which the leadership model will be used. [2] have examined the relationship between the principal leadership model and school effectiveness. However, as it is known, the concept of principal leadership model refers to the organizational characteristics or region. 
The findings related to the principal leadership model must still be tested and developed further according to the regional characteristics [2]. This study aims to examining the potential dimensions of principal leadership on the implementation of leadership of school in Sumatera Utara. Identification of determinants from the principal leadership model not only will help to determine what leadership factors are appropriate for a region but moreover, this study can predict what the critical factors of leadership effectiveness. So in the future, it can contribute to best practices and the emergence of new knowledge of leadership in educational organizations.

In the last two decades, the demand for the education sector to grow and develop continuously as other public sectors have strengthened their role in human development, it has enhanced the virtue of educational organization systems to be managed effectively [13]. Educational organization systems are increasingly complex as same as private sector organizations, so the task of leaders to manage and control these sectors became more specialized and needed [13]. To achieving good governance, requires right leader's style or model. Meeting organizational characteristics with the proper educational organization design will maximize school performance in creating superior and competitive learners. Hence this study becomes an urgent and strategic fundamental study to achieve the suitability of leadership and educational organizations which in turn will enhance the competitive advantage of educational organizations in North Sumatera in particular and in Indonesia in general.

\section{THEORETICAL FRAMEWORK}

Previous studies indicate that the professionalism of educators and education personnel depends a lot on organizational commitment. Based on empirical studies that have been conducted, the organizational commitment can be built through leadership, organizational culture, and work motivation [14]. These findings are in line with the previous study of Sagala [15], who argued that the leader's power that is used correctly would be able to leverage (leverage) and influence members of the organization to achieve goals. Power must, of course, be developed by a basic understanding and ability to accurately analyze a context from various perspectives, such as social psychology, sociology, anthropology, politics, and so on. These capabilities make organizational leaders able to consider and design appropriate behavioral strategies and according to the characteristics of members that reflect the characteristics of the organization.

Furthermore, Sagala [16] stated that a school development plan must be built in a participatory, transparent and accountable manner. This strengthens the responsibility of leaders and implies elements of organizational culture that must be present in the good governance of educational organizations. Organizational culture is not only built by the characteristics of members of the organization, but has a strong dependence on the leader figure to control the organization in a culture that supports the achievement of good governance and the achievement of effective organizations [16]. The strong role of the leader and the establishment of a healthy organizational culture will certainly immediately trigger the work motivation of members of the organization, a combination of aspects that simultaneously produce organizational commitment [16,14]. Commitments owned by educators and education personnel will in turn produce optimal educational services in building the nation's character [17].

Furthermore, Kingdon and Muzammil [18] (2012) reviewed the dynamics of educational organizations. Kingdon and Muzammil [18] argue that governance in educational organizations demands fair rewards, appropriate incentives, and professional development opportunities. These efforts will give teachers the chance to achieve competitive advantage in themselves and then be accountable for their performance in a transparent and accountable manner to leaders, parents of students, the community, and other stakeholders [18]. But to achieve competitive advantage teachers need space to move. The teacher cannot only act as the recipient of instructions. Kingdon and Muzammil [18] offer teachers to have political and legislative space through their representatives from teacher organizations. This situation gives teachers a bargaining position to develop their professionalism. From educational leadership and management, the concept does not have to be fully adopted. However, the essence of the teacher's space can be translated into the empowerment of teachers or schools as educational organizations following their competencies and competitive advantages. So that teacher performance will have implications for students' academic performance, while student performance is the primary key to school performance, and in turn, will have an impact on national education performance. However, primarily the biggest challenge for developing an educational organization is the state of the organization naturally and the ability and willingness of the organization to change or shift to a new culture [19]. While leadership is seen as the main factor that contributes to organizational success [20]. So basically leadership and organization are an integral part, and in the integration, these two variables influence and depend on each other.

On the other hand, various studies suggest that the best leadership style and organizational design are those that are consistent with the natural characteristics of individuals and their organizations [19]. The concept is known as a contingency approach, both in the leadership model and in organizational design [21]. Various transformations, shifts, and dynamics of educational organizations themselves are demanding to update knowledge in the field of education management, and one of the implications of the development of science in this study is reinventing the leadership model and design of educational organizations.

Bossert, Dwyer, Rowan, and Lee [22] asserted that referring to the contingency approach; no one managerial style is suitable for all schools. The concept supports the implementation of principal leadership styles that have developed since the 1980s and bridged the conflict between instructional leadership and transformational leadership. Researchers and academics, in general, have agreed that principal leadership has become an essential instrument in achieving school successes $[23,24]$. The principal leadership model offers a leadership model adapted based on organizational needs $[24,2]$. The initial concentration on the 
principal leadership concept is to expand leadership to include other leaders such as vice principals, department heads, and teachers themselves [25]. The focus of attention is transferred from the leader to leadership by prioritizing the importance of delegation, collaboration, trust, and empowerment in school management so that the concept of leadership has formal and distributive aspects and shows that each teacher is a potential leader [26].

However, to achieve this situation, an area must identify what kind of leadership pattern will be following the characteristics of the school and the teacher in the area. Therefore, principal leadership practices will be adjusted to the problems faced by schools so that the impact of principal leadership practices will be useful in improving the performance of school resources and ultimately will enhance the learning performance of teachers in the classroom. Previous research has offered various dimensions that build essential leadership [2,1] which must be further identified to ascertain which dimensions which possible to be implemented in certain areas. The results of the analysis of these dimensions can then be used as a basis for leadership distribution, development of regulations, and determination of school organizational models.

\section{RESEARCH METHOD}

This study was collected 325 Respondents by using survey method. We use the questioner to collecting the respond data. Distribution of respondents by gender consists of $44(12.39 \%)$ respondent are male, and $308(87.61 \%)$ respondents are female. Distribution of respondents based on education level consisted of $215(61.8 \%)$ respondents had bachelor degree and 137 (38.92) respondents had master degree. The detail of demographic sample is observable in table 1 below.

TABLE 1. Demographic Sample

\begin{tabular}{|c|c|c|c|}
\hline \multicolumn{2}{|c|}{ Descriptions } & \multirow{2}{*}{$\frac{\text { Amount }}{32}$} & \multirow{2}{*}{$\begin{array}{c}\text { Percentage } \\
9.09 \%\end{array}$} \\
\hline Age & 1. $21-30$ years & & \\
\hline & 2. $31-40$ years & 205 & $58.24 \%$ \\
\hline & $3.41-50$ years & 115 & $32.67 \%$ \\
\hline \multirow[t]{2}{*}{ Gender } & 1. Male & 44 & $12.39 \%$ \\
\hline & 2. Female & 308 & $87.61 \%$ \\
\hline \multirow[t]{2}{*}{ Education } & 1. Bachelor & 215 & $61.08 \%$ \\
\hline & 2. Master & 137 & $38.92 \%$ \\
\hline
\end{tabular}

The instrument in this study was adapted from Li's et al. [2] principal leadership instruments with some changes to suit the research needs. Researchers adapted the instrument model $\mathrm{Li}$ et al. by adjusting the question items distributed with using 5-Likert scale (strongly disagree, disagree, neutral, agree, strongly agree) to capture teachers' perceptions of principal leadership.
Furthermore, the collected data was analized using Confirmatory Factor Analysis (CFA) [27]. This study using IBM SPSS Statistics 18.0 to analyzing the CFA by the following steps:

1. Test whether the data has a sufficient correlation matrix. The test was performed using a Bartlett of Sphericity or Kaiser-Meyer-Olkin Measure of Sampling Adequacy (KMO-MSA) test. The data has a sufficient correlation matrix if the significance value in the Bartlett of Sphericity Test $<0.000$ or the KMOMSA value $>0.50$.

2. Interpreting and concluding correlation values between variables multivariate using Anti Image Matrices Correlation, with criteria: 1) MSA $=1$ then the variable can be predicted without error by other variables, 2) MSA $>0.5$ then the variable can still be predicted and can be analyzed more advanced and 3) MSA $<0.5$ then the variables are unpredictable and can not be analyzed further, or excluded from other variables.

3. Interpret and summarize the value of Extraction on the Communality output that can indicate the validity of the factor. Extraction values explain how big each item is able to explain the factor.

4. Analyze the score of eigen-value to determine how many factors will be formed. Each eigen-value $>1$ then will form one factor. It can also be determined how much each factor is able to explain the variables that are formed.

5. Analyze the component matrix values for grouping items. From Component Matrix can be determined correlation value of each variable with Factor formed.

6. If that is formed at least 2 factors then the rotation should be done. Rotation to be performed using orthogonal Rotation method in Varimax form. According to Hair, et al. [27], varimax method proved very successful as an analytic approach to get an orthogonal rotation of a factor.

\section{RESULT AND DISCUSSION}

CFA results indicate that 12 of the 33 observed items must be eliminated from data analysis because they have a loading factor of $<0.4$. Furthermore, of the 21 observed items produced five loading clumps which will then be referred to as constructs. Interestingly, the construct generated from this study shows changes in the composition of the construct from previous studies [2]. Previous research offered seven constructs of principal leadership while in this study the seven constructs were extracted into five constructs. However, if further identified, observed items removed into one construct have relatively similar characteristics. The results of the CFA analysis, in general, can be reviewed in the table 2 below. 
TABLE 2. Rotated Component Matrix ${ }^{\mathrm{a}}$

\begin{tabular}{|l|l|l|l|l|l|}
\hline \multirow{2}{*}{ Factors } & \multicolumn{5}{|c|}{ Component } \\
\hline & QM & RD & SM & EC & IL \\
\hline QM5 & .780 & & & & \\
\hline QM4 & .758 & & & & \\
\hline StM5 & .686 & & & & \\
\hline QM6 & .640 & & & & \\
\hline StM4 & .575 & & & & \\
\hline QM3 & .521 & & & & \\
\hline StM3 & .518 & & & & \\
\hline TD6 & & .736 & & & \\
\hline TD5 & & .667 & & & \\
\hline RD1 & & .570 & & & \\
\hline RD3 & & .526 & & & \\
\hline TD3 & & .526 & & & \\
\hline SM2 & & & .738 & & \\
\hline SM4 & & & .737 & & \\
\hline SM1 & & & .716 & & \\
\hline EC3 & & & & .769 & \\
\hline EC2 & & & & .681 & \\
\hline EC4 & & & & .596 & \\
\hline IL4 & & & & & .765 \\
\hline IL3 & & & & & .760 \\
\hline IL2 & & & & & .626 \\
\hline
\end{tabular}

First, the quality management constructs extracted together with the staff management construct. Conceptually the activities that occur in quality management are quite intersecting with the concept of staff management. The managerial design of these two activities is generally built with various linear policies to maintain the quality of the performance of all academic staff and staff capacity building. Referring to Blasé and Blasé [29] and Murphy [23] these various policies are a form of indirect communication built by the principal with multiple regulations, guidelines, and systems that can be referred to by teachers as their professional performance standards. So that teachers can always measure the quality of their performance throughout their duty. In this study, researchers combined various observed items that were incorporated in this construct with quality management (QM) terminology.

Second, the teacher development construct and development resource are extracted into one construct lump. In teacher education organizations are the primary resources in addition to infrastructure and stakeholders owned by the school [2,23]. The dynamics of the responses provided by respondents indicate that the actual position of human resources and non-human resources in schools in North
Sumatra have the same characteristics as a construct. These findings will have implications for principal practices that provide integrated and continuous concentration on all school resources, both teachers, infrastructure, and stakeholders. This construct is incorporated in Resource Development (RD) terminology.

Third, the strategic management (SM) construct is independent. However, of the four observed items submitted there was one observed item that did not meet the criteria $(<0.4)$. This construct shows a relatively high loading value with numbers $>0.7$. This figure shows that this construct is one of the critical factors in the potential principal leadership practices in schools in North Sumatra. In practice, strategic management is a primary managerial action that leads to strategic decision making. The strategic decision in question is decisions that can improve the competitive advantage of schools in producing excellent graduates. The decision making can be in the form of developing quality control, developing teacher capacity, collaborating with stakeholders [11,28], developing reward and punishment schemes, developing school information systems, and so on. So that it can be understood that the principal's ability to carry out strategic management is the key to the implementation of other principal leadership agendas such as quality control, resource development, and external communication.

Fourth, the external communication (EC) construct consist of three observed variables. External communication is an essential variable in the current era of globalization. To be able to become a competitive school, schools must be able to capture market demands related to alumni competencies and to achieve these competencies, and schools will need the support of interested parties, such as parents of students, government, practitioners, and industry. Collaboration with various stakeholders makes schools able to carry out more dynamic learning both inside and outside of school. Stakeholders will always provide support to schools to develop students' competencies. Furthermore, if external communication has resulted in collaboration between schools and external parties, the school will continue to be in a circle that demands it to continue to increase school capacity $[2,11]$.

Fifth, the Instructional leadership (IL) construct consists of three loading that meet the criteria. The third number obtained is quite large, namely two of them $>0.7$ and one of them $>0.6$. The figure shows that instructional leadership is the next dominant dimension in forming principal leadership. Previous research has revealed that in teacher education organizations have a dependence on explicit instruction in carrying out tasks $[11,29]$. Instructional leadership plays a role in assisting teachers in solving practical and tactical problems with quick feedback from the principal, besides instruction can also be in the form of direction involved in training, a community of practitioners, researchers, and learning innovations that lead to teacher development [23]. 


\section{CONCLUSION AND RECOMMENDATION}

In the last two decades, the world of education has gained significant attention and urged it to proliferate as other public sectors [13]. These demands lead to the development of human resources. Meanwhile, in various educational organizations, several experts have agreed that leadership is a crucial instrument to maximize organizational functions including human resource development $[1,2,3,4,5,6]$. The stagnation of leadership practices immediately results in stagnation in the growth of school capacity. Unfortunately, the stagnation of the practice is linear with the stagnation of educational leadership theories that consume a lot of energy in the debate between transformational and instructional leadership in schools. Whereas in the last two decades leadership researchers have provided recommendations on alternative leadership models namely principal leadership $[23,24]$.

This study explores the potential of principal leadership practices in North Sumatra by examining seven principal leadership constructs developed by Li et al. [2]. With the CFA, this study received confirmation of the seven constructs extracted into five key constructs that are relevant to the characteristics of educational organizations in North Sumatra. Therefore this study recommends policymakers to consider these five criteria so that they can be regarded as competencies that must be possessed by the principal. These constructs are Quality management, Resource Development, Strategic Management, External Communication, and Instructional Leadership. The principal must be able to carry out these five leadership instruments to help him produce effective and competitive schools.

Practically this study can be used as a reference for regulators to complete the instrument of competency indicators in determining and appointing principals. Furthermore, principals can make the results of this study as a reference to improve the quality of governance in the organization they lead. Schools can implement various concepts proposed in this study, and further improvements will be made to achieve best practices. Furthermore, theoretically, this study has produced a relatively new idea in the repertoire of education management research in Indonesia. Researchers can then test these findings in practical implementation so that they can produce internal validity from a research finding. Further research can also explore these five variables into a structural research model that can be more implementable to be applied practically.

\section{REFERENCES}

[1] Leithwood, K. (2016). Department-Head Leadership for School Improvement. Leadership and Policy in Schools, 15(2), 117-140.

[2] Li, L., Hallinger, P., \& Ko, J. (2016). Principal leadership and school capacity effects on teacher learning in Hong Kong. International Journal of Educational Management, 30(1), 76-100.

[3] Harris, A. (2004). Distributed leadership and school improvement. Educational Management Administration \& Leadership, 32(1), 11-24.

[4] Marks, H. M., \& Printy, S. M. (2003). Principal leadership and school performance: An integration of transformational and instructional leadership. Educational administration quarterly, 39(3), 370-397.

[5] Printy, S., Marks, H., \& Bowers, A. (2010). Integrated leadership: How principals and teachers share transformational and instructional influences. Jsl Vol 19-N5, 19, 504

[6] Bush, T. (2016). School leadership and management in England: the paradox of simultaneous centralisation and decentralisation. Research in Educational Administration \& Leadership, 1(1), 1-23.

[7] Sagala, S (2006) Manajemen Berbasis Sekolah Dan Masyarakat: Strategi Memenangkan Persaingan Mutu. Jakarta: Nimas Multima.

[8] Sagala, S (2010). Supervisi Pembelajaran Dalam Profesi Pendidikan. Bandung: Alfabeta.

[9] Sagala, S (2017) Memahami Organisasi Pendidikan: Budaya dan Reinventing Organisasi Pendidikan. Jakarta: Kencana Prenada Media Group.

[10] Hallinger, P. (2003). Leading educational change: Reflections on the practice of instructional and transformational leadership. Cambridge Journal of education, 33(3), 329-352.

[11] Robinson, V. M. J. (2009) Fit for purpose: An educationally relevant account of distributed leadership. Distributed leadership. Netherlands: Springer, 219-240.

[12] Hofstede, G. (1983). The cultural relativity of organizational practices and theories. Journal of international business studies, 14(2), 75-89.

[13] Fielden, J. (2008). Global trends in university governance. Education working paper series, 9, 278200-1099079877269.

[14] Surbakti, R. B., Sagala, S., \& Sitompul, H. (2016) The Effect Of Cultural Organization, Leadership, Motivation Work, And Job Satisfaction Commitment To Organization (A Case Study In Madrasah Aliyah State North Sumatera). International Journal of Educational and Research Vol. 4 No. 4

[15] Sagala, S. (2012) Tantangan Dan Peluang Perilaku Organisasi Yang Efektif, FORMASI: Jurnal Kajian Manajemen Pendidikan Vol. 13 No. 1

[16] Sagala, S. (2013) Menyusun Rencana Pengembangan Sekolah dengan Prinsip Partisipasi, Transparan, dan Akuntabel, Jurnal Manajemen Pendidikan Indonesia, Vol. 5 No. 1

[17] Sagala, S. (2011) Membangun Menara Pendidikan Berkarakter Cerdas, FORMASI: Jurnal Kajian Manajemen Pendidikan Vol. 12 No. 1

[18] Kingdon, G., \& Muzammil, M. (2013). The school governance environment in Uttar Pradesh, India: implications for teacher accountability and effort. The Journal of Development Studies, 49(2), 251-269.

[19] Garrison, D. R., \& Vaughan, N. D. (2013). Institutional change and leadership associated with blended learning innovation: Two case studies. The internet and higher education, 18, 24-28.

[20] Adserias, R. P., Charleston, L. J., \& Jackson, J. F. (2017). What style of leadership is best suited to direct organizational change to fuel institutional diversity in higher education?. Race Ethnicity and Education, 20(3), 315-331.

[21] Gregoire, M. B., \& Arendt, S. W. (2014). Leadership: Reflections over the past 100 years. Journal of the Academy of Nutrition and Dietetics, 114(5), S10-S19. 
[22] Bossert, S. T., Dwyer, D. C., Rowan, B., \& Lee, G. V. (1982). The instructional management role of the principal. Educational administration quarterly, 18(3), 34-64.

[23] Murphy, J. F., Weil, M., Hallinger, P., \& Mitman, A. (1982). Academic press: Translating high expectations into school practices and classroom practices. Educational Leadership, 40, 22-26.

[24] Hallinger, P., Bickman, L., \& Davis, K. (1996). School context, principal leadership, and student reading achievement. The Elementary School Journal, 96(5), 527-549.

[25] Ayres, P. L., Sawyer, W., \& Dinham, S. (2000). Successful senior secondary teaching. Australian College of Education.

[26] Dinham, S. (2005). Principal leadership for outstanding educational outcomes. Journal of educational administration, 43(4), 338-356.
[27] Hair, Jr., J. F., Black, W. C., Babin, B. J., and Anderson, R. E. (2010). Multivariate Data Analysis: A global perspective ( $7^{\text {th }}$ ed.). Upper Saddle River, NJ: Pearson Prentice Hall.

[28] Blase, J., \& Blase, J. (1999). Principals' instructional leadership and teacher development: Teachers' perspectives. Educational administration quarterly, 35(3), 349-378.

[29] Goldring, E., Porter, A., Murphy, J., Elliott, S. N., \& Cravens, X. (2009). Assessing learning-centered leadership: Connections to research, professional standards, and current practices. Leadership and Policy in Schools, 8(1), 1-36. 